\title{
NEW FUNCTIONS OF OLD CITIES: THE CASE OF EAST GERMANY'S SMALL SIZED CITIES
}

\author{
Youkyoung Sung, Bauhaus University Weimar
}

\begin{abstract}
Cultural tourism associates itself with complex issues of dealing with urban memory. As a connotative communication channel, tourism sites and monuments are a perspective through which a city speaks for itself. A number of tourist destinations in the former GDR state faced drastic changes in their tourism management after the national unification of Germany. Which voice does the cultural heritage contain in these cities along its dissonant history and how the local perceptions on the heritage have been altered in the last 25 years are the main subjects of this research.

Based on the former studies on the topic of 'heritage and urban identity', this paper explores the relation between architectural heritage management and the dwellers' perceptions on the heritage since the removal of visa controls between GDR and BDR in 1989. Compared to the economic and political studies after the German reunification, socio-cultural issues on local identity and cultural re-adaption process have not been much discussed. Taking three exemplary cities in Thuringia (Eisenach, Gotha and Weimar), the document analysis of the conceptual changes in cultural tourism management and qualitative interviews on both authorities and residents will be done. By providing empirical data on the ongoing German governance, the author attempts to explore the role of cultural heritage in Germany's urban resilience. Furthermore, this research aims to contribute to the contemporary agenda on cultural tourism management in multi-identity societies over international borders.
\end{abstract}

Keywords: Cultural tourism, Heritage, Urban identity, GDR (German Democratic Republic)

\section{NOVE FUNKCIJE STARIH GRADOVA: SLUČAJ MALIH GRADOVA ISTOČNE NEMAČKE}

\section{Sažetak}

Kulturni turizam se povezuje sa kompleksnim pitanjima tretiranja urbanog nasleđa. Kao konotativni komunikacijski kanal, turistička mesta i spomenici predstavljaju perspektivu kroz koju grad govori o sebi. Izvestan broj turističkih destinacija u bivšoj Nemačkoj Demokratskoj Republici (NDR) je pretrpeo drastične promene u turističkom menadžmentu nakon ujedinjenja Nemačke. Glavne teme ovog istraživanje odnoso se na pitanja koji glas odražava kulturno nasleđe ovih gradova imajući u vidu njihovu disonantnu istoriju i na koji način su lokalne percepcije nasleđa menjane u proteklih 25 godine. Na osnovu ranijih studija na temu „nasleđe i urbani razvoj“, ovaj rad istražuje odnos između upravljanja arhitektonskim nasleđem i percepcije tog nasleđa od strane žitelja od momenta ukidanja viznog režima između NDR i SRN 1989. godine. U poređenju sa ekonomskim i političkim studijama urađenim po ujedinjenju Nemačke, sociokulturna pitanja lokalnog identiteta u procesu kulturne readaptacije nisu bila mnogo obrađivana. Na primeru tri grada u Turingiji (Ajzenah, Gota i Vajmar), biće analizirani dokumenti koji svedoče o konceptualnim promenama u menadžmentu kulturnog turizma, kao i kvalitativni intervjui lokalnih vlasti i žitelja tih mesta. Pružajući 
empirijske dokaze o trenutnoj nemačkoj vlasti, autorka nastoji da istraži ulogu kulturnog nasleđa u urbanoj sredini Nemačke. Ovo istraživanje ima za cilj i da doprinese savremenoj agendi o upravljanju kulturnim turizmom u multiidentitetskim društvima, bez obzira na međunarodne granice.

Ključne reči: kulturni turizam, nasleđe, urbani identitet, NDR (Nemačka Demokratska Republika)

TIMS Acta (2015) 9, 115-125

\section{Introduction}

Celebrating the 25th anniversary of the fall of the Berlin Wall, Germany has now the chance to reflect the past years in terms of different societal aspects. The 30 years of ideological and physical partition are still one of the main characteristics people associate with Germany, but certainly not as the most glorious moments of the national history. Being separated into two different political systems caused huge political estrangement. The consequences of this era certainly require extra attention, even until now. It is not comparable to any other case of political interruption in modern history. However, what needs more attention at this point of time is not limited to politics. The reunification has created also cultural and social challenges. The interruption of communication within the nation brought drastic changes in people's daily lives. Social values, roles of the municipality, freedom of travel and the tourism culture all inclusively have been manipulated during the socialistic government. What came after the reunification was, apart from political changes, a huge dissonance among the people.

The first happening which directed into the reunification between FRG (Federal Republic of Germany) and GDR (German Democratic Government) was the removal of visa controls in 1989 (1.11.1989). On the 19th of December, after the fall of the Berlin Wall, tourism professionals gathered in Dresden (former GDR) to discuss the economic development of tourism between West and East German states. As the GDR was almost a closed country for outbound tourism and only allowed a limited number of inbound tourists, the former GDR state was expected to attract a large number of visitors and at the same time, active tourism from the East to the West was foreseen.

Tourism can show the social understanding between what the place wants to tell about itself and what outside visitors want to discover there. In the context of the former GDR state, it is a task for today's generation to decode what has been told in the past and to decide what is going to be told in the coming decades. Since a city alone cannot extract the whole information of physical history of the places, tourism industry often focuses on the most preferred stories that the citizens want to tell or the visitors might want to hear. Having a close look at the former GDR cities is, therefore, a way to read how the cities have been defining themselves in the last 25 years.

Another issue which plays an important role in the region of the former GDR state is the economic pressure. After the collapse of socialistic idealism, the former GDR population had to go through a tremendous transformation from the socialistic allocation system to the capitalistic competitive market. While there was no concept for city marketing and tourism industry in the former GDR, the cities had to suddenly deal with commercializing and building own charms to attract people. After the system change, tourism was no longer vacation distribution - where people get allocated with accommodation and vacation schedule - but became a competitive market among tourism destinations. The pressure to generate economic resources was a definite booster to build facilities for tourism such as traffic system, hotels, restaurants and amusement facilities. While adjusting the touristic infrastructure for the free market competition, there was little public discussion about how to process the decisions, which touristic monuments to preserve and where to support the establishment of touristic destinations.

Tourism development in the former GDR region is a rather neglected topic in academic circles considering its drastic changes in the last 25 years. Discussions over political and economic changes have led the research trend. Urban renewal on the façade and infrastructure 
changes happened in constant basis since the reunification however, it did not bring much conceptual discussions on urban tourism as its result. Until now, tourism studies on the former GDR states are relatively limited compared to the ones on West Germany and exclusively lacking when it comes to the sociocultural context in a relation to the reunification. Exclusively, there is a tourism system transformation analysis by Freyer (2000) and a study on tourism conception change by Wolter (2009). These two studies are very helpful to understand the system change in political levels however, empirical and qualitative studies on specific regions are still to be explored and further discussions on tourism industry after the structural changes are in needs.

Due to its geographical and historical features, the towns in the state of Thuringia have developed a focus on cultural tourism. Its rich assets of important historical figures such as Goethe, Schiller, Bach and Luther are at the moment the factor which brings the biggest portion of tourism income to the towns. From the castle where Martin Luther translated the first German version of bible and Goethe's house, Bach's birth place and up to the statue of Goethe and Schiller, Thuringia is now, as it recently promoted itself, the heart of German culture. Surely cultural tourism is what Thuringian economy is standing for. During the GDR era, however, these heritage potentials were much less emphasized compared to today. Its value as an economic booster and symbol of the locality has developed along with the transformation towards a capitalistic state. Cultural tourism destination development can be seen as an example of urban adjustment after the influence of political ideology on tourism had ceased.

The main topic of this paper is the role of cultural heritage in tourism in East Germany. The paper aims to explore the following research questions: How were decisions concerning tourism processed during the political transformation in the region of the former GDR? How was the past urban heritage defined? What was chosen to focus on in order to build on the local history form a local identity? This paper aims to fill the research gap by providing detailed information on the former GDR region. Also it attempts to bring an exemplary study on heritage dualism/plurality in one territory for other nations or communities.

\section{Method}

Since the connection between the political changes and cultural tourism in the former GDR state has not yet caught much attention, it was a fundamental difficulty to find information sources and get enough data for the research. Although the information of authority changes and tourism attractions is open for the public, it is difficult to back up the sentiments and functions of certain heritages before and after the reunification. In order to achieve the maximum of the research material, interdisciplinary methods are colloquially applied. Tourism guide books from the GDR era, GDR heritage lists, internet archives of the GDR documents and present tourism brochures of the municipalities were reviewed as background data analysis. For the empirical qualitative research, a combination of expert interviews and focus group interviews are conducted.

To analyze the consequences of the heritage management on the locality, the paper reviews former studies on heritage and identity, tourism and urban identity, memory management and heritage tourism. It connects the relation between the 'chosen' heritage and the contents that it brings in the former GDR state. To see how the process has been managed, an empirical study on the state of Thuringia is done, with a special focus on the three case cities, Eisenach, Gotha and Weimar. These three cities are, except of the capital city of Thuringia (Erfurt), the most visited cultural tourism destinations. To name the main characteristics, Eisenach calls itself Luther and Bach city, Weimar is seen to be Goethe and Schiller's representative inspirational city and Gotha is a historic city with an enormous baroque castle. These cities have in common well preserved old towns and a number of stories with important figures of German history.

The empirical part of the research clarifies the interactions between authorities and dwellers. The data regarding the view of the authorities were collected through document analysis and expert interviews with the tourism marketing agency of Thuringia. Since there is not a main institute which dealt with cultural tourism for the last 25 years, it was analyzed by various materials from what the researcher could collect. For the record of historical factors, such as laws and authority 
transformation, local archives were mainly used and the documents published from different institutions were analyzed. Twice of expert interviews with the tourism agency in the state of Thuringia, 'Thüringer Tourismus $\mathrm{GmbH}^{\prime}$, have been conducted and the projects and plans of this agency are used mainly for the part of local tourism development plans.

For the dwellers' perspective, twice of focus group interviews (with 7-8 citizens), semi-structured interviews and narrative interviews with elderly citizens (from 64 year) have been conducted. Since the data depended much on personal memories of the past decades, it was important to build personal trust with the interviewees. Also it was essential to note which comments to be taken as an objective testimony because of the partly moody answers which had been given depending on the personal experiences during the GDR era.

\section{Results}

Tourism in the GDR had most of all three definite functions which are certainly different from how tourism is usually understood in capitalistic countries. It is strictly ranked by the importance: political function, social function and finally comes the economic function (Freyer, 2000, pp. 218-219). Apart from the third economic function, the political and the social function are unique in the GDR and it represents the ideology of tourism in this time and how the destinations were managed. The political function stands for the maintenance and consolidation of the state power and developing socialist consciousness. This has affected the consolidation on holidays by community events and communal schedule at the vacation place. The social function means contribution to socialist culture. It is interpreted as "body culture" and the all-round physical and mental development of socialist citizens. Travel/Tourism/Vacation was understood often as a reward which was not easy to gain due to limited space at tourist destinations. The economic function is also not as an economic generator but it was meant mainly "reproduction of social labor-power." 1

The fact that the economic function of tourism was clearly below the first two functions shows that tourism in the GDR was understood not as an industry but rather as a public service, which supported the socialist ideology. Economic function of tourism aimed also at the economic profit but in the sense of letting every GDR citizen to have a chance to rest and recharge themselves in order to stay effective and productive for the rest of the working seasons (Jensen, 2013, p. 15). It implies two factors important for the understanding of GDR tourism: Firstly, tourism was focused on rest and refreshing oneself rather than exploring cultural heritage and trying extraordinary experiences. Secondly, it anticipates that the GDR tourism destinations were generally nature centered places.

Regarding the tourism culture in the GDR time, it is assumable that cultural heritage did not function preferably as a tourism destination even though many historic districts relate themselves directly as tourist destinations elsewhere (Allison \& Peters, 2011, p. 135). It experiences however drastic changes and investments right after the German reunification. Parallel to the tourism culture, heritage conservation directly shows the different values of the society, explaining how they perceive the importance the classic while commemorating Germany's shared past.

According to Graham, heritage studies have been developed by time more enthusiastically than ever (Graham \& Howard, 2008, p. 1). He argues that we adopt perspectives in which very selective historic artifacts, natural landscapes, memories and traditions become cultural, political and economic resources for the present. In this way, the former GDR population has been through a different social education than the other West Germans which might still affect their way of seeing the past. As the communist ideology has influenced much more on the life style of the population, the politics influenced almost every sector of the society.

After the end of the Second World War, Germany was in a hurry with rebuilding the war ruins and occasionally commemorating the scars in the architecture. The architecture commemoration process in Germany has processed in two different ways in two different ideologies and that still leads discussions on 'how to remember' the past. As if every system tried to build an own identity by establishing an own system dealing with the common past, the FDR and GDR have developed heritage conservation law each in 1973 and 1975. The GDR government declared that a national 
monument has to meet historical, artistic or scientific importance in the interests of socialist society (Ges. 19. Juni 1975, Paragraph 3).

Historical Heritage in the GDR was categorized into political history/ cultural history/ folklore/ special sites for revolutionary developments on productivity and transportation. Architectural and Art Heritage was categorized into heritage of city planning/ architectural heritage/ heritage of fine arts and crafts/ heritage of the landscape and garden design. In the classification of monuments in the GDR, there was a republic list for those objects that were assessed to be the most significant. Below that there were, in hierarchical order, the lists of districts and municipalities. All lists required confirmation by political committees or depends on the case, the council of ministers, i.e. (Schmidt, 2008, p. 67). Following the criteria, the GDR cultural heritage list is consist of many socialist symbols, statues and places.

In January 1990, with the start of "Europäisches Jahr des Tourismus" (European year of tourism), it was aspired for everyone of the tourism sector in the GDR to make the former GDR cities to be a successful tourism destination. Among the number of visions and plans, the organization of tourism destination development was not much asked to the citizens but mostly done by the "topdown" policies (Freyer, 2000, p. 36). Freyer describes this moment of the GDR tourism as "the rollercoaster run" in German history in her book, "Tourismus in den neunen Bundesländern (Tourism in the new federal states)". The drastic and sudden politic transformation brought changes in every category of the citizens' life and tourism sector experienced rapid privatization and capitalization.

Hans-Jürgen Wolff, the first marketing manager/ coordinator of the $\mathrm{DZT}^{2}$ for the new states of Germany (NBL: Neue Bundesländer). He notes the transition year of 1989-1990 that the former GDR states were critically lacking the concept of market competition, image commercials for successful local tourism and offers for tourists. All the market oriented communication tools and promotions were not comparable to the standards of West Germany. At the beginning, the disproportions of the necessary industrial promotions and infrastructure development were critically in need of improvement. "Ecological legacy" magnified the negative image of the NBL (Freyer, 2000, p. 45).
Commercialization in tourism meant also that each regional government had to develop its own charm and attractions for the market competition. Former "Reisebüro (travel agency/office)" which was under the ministry of traffic and organizing the vacation plans of the GDR citizens, lost its function with the collapse of the socialist system.

As nature tourism was beloved during the GDR, the Thuringian forest was once one of the most popular tourism destinations. East Coast, Thuringian Forest, and Harz region ${ }^{3}$ have consisted of the top three tourism destinations in the GDR (Freyer, 2000, p. 232). According to a statistic, $80-90 \%$ of tourism market was concentrated in inland tourism and following the East coast, Thuringian forest was the second popular tourism destination during the GDR (Deutscher Tourismusverband e.V.2002, S.46).

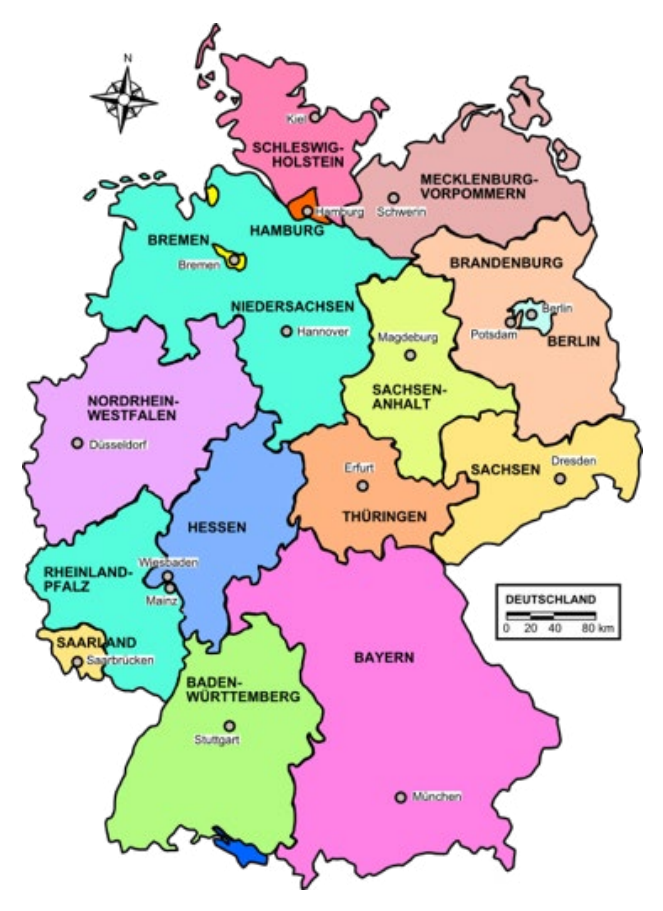

Figure 1. The state of Thuringia in Germany

While heritage tourism was in big neglect, Thuringian forest faced a risk as a quality tourism destination. Firstly, because of the newly appeared numberless tourism destinations for unified Germany and, secondly, the change of the tourism concept from the recovery orientated purpose to the various needs of individuals. 


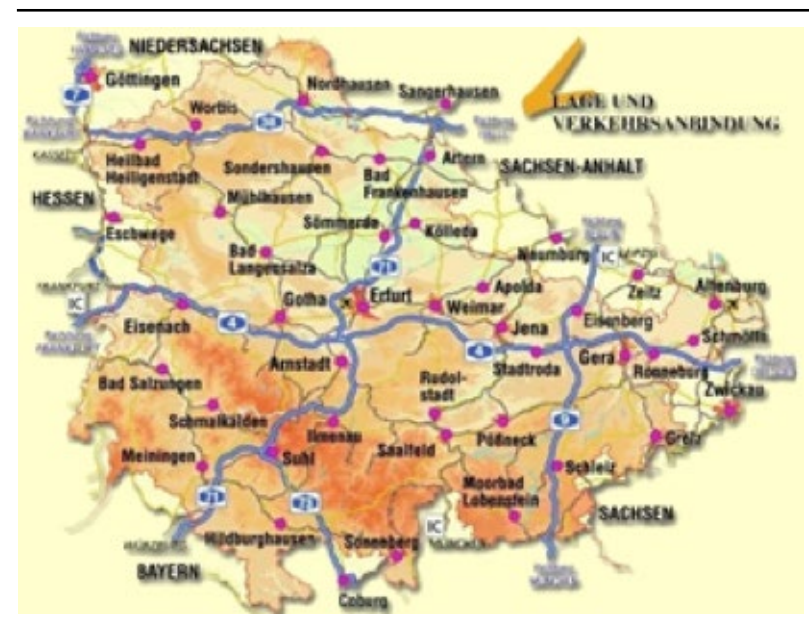

Figure 2. Thuringian Geography

Proving this, Thuringian regional travel agency shows clear direction as its focus on cultural tourism since 2000, when the present agency took over the administration of regional tourism. According to a statistic from the ministry of economic affairs, employment and technology of Thuringia in 2012, 35\% of private tourists in Thuringia are cultural tourists. This is a significant number as the German average cultural tourist is $25 \%$ (Freistaat Thüringen, 2012).

According to the report of "Tourism concepts of Thuringia 2011-2015", culture is the key differentiation for the tourism of Thuringia. Cultural tourism is titled as the number one plan out of eight different tourism development plans and the report points out the unique characteristics of cultural charms of the state. "Culture and Cities" (Kultur and Städte) is the main motto of tourism theme and it also adds the background information of competitive tourism industry to cope with the theme of "Nature and Activity" (Natur und Aktiv), one of the existing concepts of Thuringian tourism ${ }^{4}$.

Thuringian tourism agency 'Thüringer Tourismus GmbH (TTG)' is in charge of regional tourism marketing and its marketing manager, Rainer Engelhardt has been working for the TTG since 1990.

According to Engelhardt, after the reunification a number of Thuringian cities faced economic crisis. Smallmedium sized cities such as Altenburg, Greiz and Gera have completely lost its main role as an industrial city and also as the former capital city of Bezirk ${ }^{5}$ in the case of Gera. Fortunate cities such as Eisenach, Weimar and Gotha have historic charms which play a dominant role to bring more jobs and sustain the city.

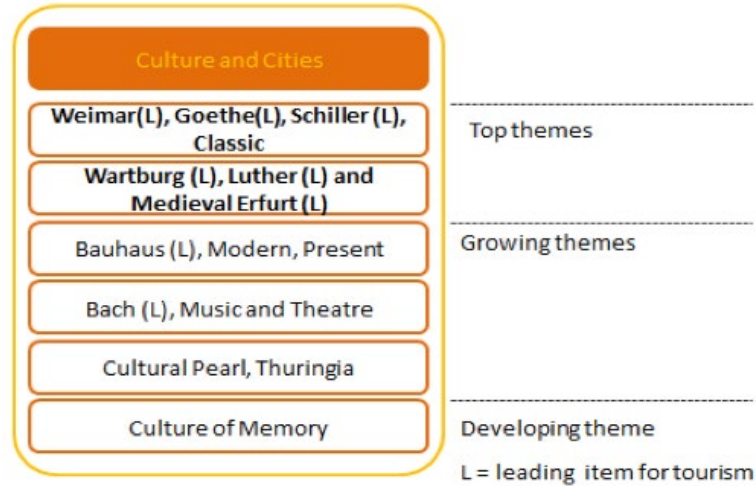

Figure 3. Priorisation of tourism themes: culture and cities (Ministry of economic affairs, employment and technology of Thuringia, Tourismuskonzeption 2011-2015 2012, P.38

In other cities the citizens leave the city in order to find jobs. A severe example is the case of Altenburg where the population has shrunken to about one quarter of how it used to be in the GDR.

Engelhardt explains that in the case of German visitors, the majority of tourists who visit Thuringia the first time are cultural tourists who organize their trips by themselves. They usually visit Eisenach, Erfurt and Weimar. The important figures and their traces in these cities are probably what they heard of and wanted to visit at least once in their life time. From the ones who liked it, the second visit would continue to the other smaller cities and also to the Thuringian forest. In the case of foreign visitors, because of its geographical location, the aim is to encourage them to make a little stop in Thuringia on their way between bigger cities such as from Frankfurt to Berlin. The thematic approach is in this case also important because such as Luther and the story telling from Luther's traces can attract certain group of people to visit Luther related places all over in Thuringia. The focus of tourism management is therefore, mainly aiming at Germans and to make them return for other activities in Thuringia. The recent research says that $93 \%$ of the visitors are German in whole Thuringia. According to the ministry of Thuringia, tourism industry in the region has increased in sum 31.8\% in 2000 to 2008 (Wirtschaftsfaktor Tourismus in Thüringen Endbericht, 2009) and it is now the fastest growing industry in the region (Freiestaat Türingen, 2015).

While the former concept of tourism for the GDR citizens used to be a travel applied by the companies, the concept of cultural tourism is newly approached after 
the reunification. Cultural monuments were also visited in case of daily school trips or picnic with colleagues. Weimar and Eisenach were the one of the most visited school trip destinations and nowadays it has been spread out to bigger choices such as far to the west or often to the neighbor countries.

An interesting fact about Weimar has been discovered during the expert interview. Weimar is now, as well as in the past, a beloved place for educational school trips. However, the contents of the trip seem to be not exactly identical. The former concentration camp from the WWII, the Buchenwald, is until today one of the most promoted sightseeing places in Weimar. During the GDR, visiting Buchenwald was also a very common route of the trip but it was not only to remember the historical tragedy but also to learn the sacrifice of Ernst Thälmann, the communist hero who was murdered in this camp. His statue was an important symbol of Weimar and for this reason it was often a tool of communist education system to visit the city. The memorial place of Ernst Thälmann was after the collapse of the GDR completely abandoned for almost for a decade and only attracted little attention during the last 10 years. Nevertheless, the statue and Thälmann's death in Buchenwald is not anymore an important topic for Weimar.

Opposite to Thälmann's memorial, 'the new museum of Weimar' was completely run down at the end of the GDR regime. With huge efforts of fund raising, after nine years in 1998 , it re-opened. So did however basically almost every old edge of the cities has been through a drastic renovation and investment. Meanwhile, during these first few years, the communist heritages were out of the sight for the citizens but also for the municipal tourism management.

As a correspondence to this, Holzhäuser ${ }^{6}$ records the busy changes of the urban façade. The old town of Gotha, where she worked over 30 years, has been totally renovated and the city was suddenly painted with colors. She tells a story about an American tourist who she met in Weimar's local bus. The tourist had some wishes where to visit and she as a local, was not aware of several places and she had make a tour with her for hours.

Böhme $^{7}$ is born and has lived her entire life in Weimar. In her memory, Weimar has been always an important city for German history and what makes herself feel typical Weimar, she says it is Buchenwald. She stressed about the importance of remembering what happened in the concentration camp at the same time what this means to the city. Also she mentioned the importance of the statues of Goethe and Schiller and many other artists who produced important pieces in this city.

Through two rounds of focus group interviews with Weimar citizens aged from 64-78, the biggest change of tourism culture, was recognized as simply the way of tourism. With the question of holiday/vacation culture and tourism memory, the answers returned always as the stay at coasts and mountains. As it was led during the socialist system, the placement in rich nature was most preferred and enjoying the seldom opportunity to travel the farthest place such as East coast was popular. Short trips to near neighbor cities could be organized by personal motivation, however school or any communal trips involved political intentions to visit important places for socialist ideals.

Urban heritages such as oldest streets of Weimar and squares have changed its name after the reunification and people still share the old names and the old names for frequently told among them. For example, one of the largest streets of Weimar, on which Ernst Thälmann's memorial is also located, used to be called as Leninstraße (Lenin Street) and now it is adjusted to Karl August Allee since 1991.

The education by socialist system was not only by the schools but also through all the elements in daily life and that relates until now the adjustments of the former GDR population. Small cities like Greiz have lost its function since the reunification because there was no more need of fabric industry from this town. It was rather imported from all over and its manually done handmade pieces were not any more competitive enough in capitalism.

\section{Discussion}

Looking at Germany's modern history brings a couple of topics which are certainly unique and complex. The German cities, especially the cities in the East part of Germany (former GDR state), have been through two enormous political events: the Second World War and communism which cannot be compared with any other 
locations in the world. Urban heritage, as a physical testimony, shows the different angles they have been through. Even if one society eliminates a heritage and ignores it, it already speaks for the perspective how the society wants to deal with this certain architecture or related factors.

Present-centerness applies in order to understand the heritage management in Germany. It follows the theoretical background that the way of looking at heritage does not involve a direct engagement with the study of the past. However, the contents, interpretations and the representations of the heritage resource are selected according to the demands of the present (Lowenthal, 1985; Ashworth \& Graham, 2005; Ashworth \& Larkham, 1994; Ashworth \& Graham, 2005; Graham \& Howard, 2008). What is valuable and to be remembered depends on how the contemporary society sees them, such as the case of the former GDR heritages. From the central heritage list of the GDR, most of the socialist symbols and statues are removed from the list afterthe reunification. Promoting tourism based on the urban heritage is another clear sign to see what the locality wants to communicate to the public. There are still a number of factors which influence what is needed to be shown, however, there are also a number of things which disappear during this active movement of 'remembering'.

Who decides what is to be remembered? There is power involvement while remembering a certain period or a certain story of the community, and the 'doer' or the 'marker' must be an influential power of the society. Firming up the shared memory and supporting the local identity have been always repeated in human history. As Passi (1999) argues, spatial practices which bolster and sustain the power of the dominant group are essential components for that group's control over the hegemonic values that it represents or imposes (Passi, Inder Bir S. 1999). Graham and Howard say that national government, as a dominant power, often constructs cities with memory such as monuments, plaques, museums, and symbolic architectural spaces, as static and permanent reminders to represent hegemonic values that cultivate notions of national identity and frame ideas and histories of the nation (Graham \& Howard 2008, pp. 44-45).
After the collapse of the GDR, large parts of old towns in the former GDR state were saved by public funds as well as public donations (Schabe, 1992; Schmidt, 2008, p. 69). While repossessing the urban heritage of the former GDR, Germany has been through the selection process of remembering. Re-creating regional and national image and locality is included in the process and in tourism it can be a part of city branding as well.

Harrison suggests that the process of forgetting is in fact integral to remembering that one cannot properly form new memories and attach value to them without also selecting some things to forget (Harrison, 2013, p. 580). What was chosen to be remembered after the German reunification was the earlier past before the national division happened. The museum, the churches, the old towns and places which involve important figures in German history were saved in the immediate rescues. While doing so, through consequent nature, most recent history of socialist urban landscape was faded out. Deliberately or not, the confusion right after the regime change chose concentrating on 'the classic' over commemorating 'the new' heritage without a manual explaining how to deal with the ideological heritages which are against to the re-conquering power. It was a worldwide extraordinary experience and it is still not a common topic to talk about in this region how to deal with the past urban memories as a single human.

Meanwhile, the citizens of the former GDR was in cheer for the renovation of urban façade. Finally, their home town was saved from crumbling into grey ruins. Witnessing the urban changes was one of happy moments of the reunification, the citizens say. The process of heritage-making and processes of listing reminds of colonial heritage issue and question of 'otherness'. In certain places, some groups are considered 'others', that is, not belonging and out of place, while dominant groups marginalize these 'minorities' in order to preserve the characteristics and qualities of 'their' place (Ashworth \& Graham, 2005, p. 155). While postcolonial politics often tend to acknowledge the difference between two layered cultures (Kearns \& Philo, 1993), the past heritage was out of the sight and out of discussion in the GDR period. Thus, it is not fully explainable by inclusion and exclusion either. In the former GDR state, the process of destination making, the local involvement 
in the generated job market and regional economy and mostly the joy of having visitors in the city disprove the concept of 'otherness'. It was mostly political top-down organized policies but most of the urban renovation and improvements on infra-structure for tourism (most of them helped also the local fundamentally) were longed for by the citizens.

It is easier to point out what/who has the power to make certain artifact more visible. Promotions, commercial events, infrastructure such as traffic and public funds can make certain locations more interesting in other words, more evident. Cultural festivals such as Oktoberfest in Munich and Carnival in Colonia show the example of cultural festival as a contribution to city marketing and economic generator. By tourism, a community can develop its local identity in a communicative way. What people want to see is also involved by the economic demands and especially in the case of cultural tourism it shows clearly what we want to experience by taking the effort and money to live the short moments at the place of history. Therefore, it needs constant attention to lead the development of cultural tourism the way the society wants to go in the future.

Graham argues that even within a single society, pasts, heritages and identities should be considered as plurals. It means not only do heritages have many uses but they also have multiple producers (Graham \& Howard, 2008, p. 1). A single society has different layers of pasts, heritages and identities and what we see in present must be a selected perspective out of the plurals which cannot be explained all at once.

"It is vital to understand how place identities are formed and how localities and their histories play a role in this process. For academics, at least, identities are seen as social constructs that are continuously contested between actors. As identities deal with elusive concepts, such as meanings and values, actors produce and reproduce representations of places in this process of contestation." (Ashworth \& Graham 2005, p. 193)

What could have been done better is not the point of the study but it can be a productive lesson for many other societies, facing plural cultures and perspectives within a territory. An important issue from Germany's case is now, how to embrace the shared memory of the partial population in a sensible way.

\section{Conclusion}

Germany's case shows how heritage interplays with the political changes of the society. After the communist power ruled every edge of the urban space, there was little information on how the urban landscape was reorganized. Celebrating the reunion has drawn attention to the shared past and the concentration of budget and regeneration to the collective national history. A number of renovations have been happening in the last 25 years and cultural tourism has become a popular topic in the former East Germany.

Until now there has been little discourse about how to re-possess the heritage which has been through different preservation for decades and on the other hand how to deal with the heritage retained during the socialist system. After 25 years of the national reunification, cultural tourism has become an important characteristic of a number of cities in the former GDR and heritage promotion is a common source of tourism destination development.

Germany is a unique case of a reunified country after a physical partition in two different ideologies. When the Berlin Wall fell, there were no former remedies for reoccupying the territory. It can be however a case study for other nations or cities where layered perspectives exist. Due to geographical reasons, religions, races and minorities, there is a growing number of spaces with political tensions and heritage issue is enclosed in the core debate.

Cultural tourism in the former GDR involves two fundamental background issues in this region.

1. Locality

2. Economic resource.

While redefining the historic assets, the criteria to see what is to be remembered have been through a big gap of two different ideologies. Heritage list in the GDR included not only the classic heritage which used be in care before the national division but more importantly, it ranked the socialist architecture on the central heritage list which is prioritized over the other two, 'Bezirk' and 'Kreis (district or area)' heritage list. Selection of heritage is a barometer to see what was valued in the community and by commemorating the selected ones it educates the local people in the daily life. 
Confusions and speedy investment right after the unexpected national reunification has put the 'new heritage issues' aside but concentrated to the classic national artifacts and figures. The retained heritage from the socialist system has lost its meaning and it still remains unclear how to deal with it. Most important is how the local people deal with their shared memory about the 'used to be important' but 'lost' heritage in their neighborhood.

The pressure for quick adjustment to the capitalist urban management and tourism destination development has been generated from different directions. The federal government put effort to improve the tourism infrastructure in order to achieve some balance as in was in the West: building highways, hotels and the federal train system. Within the cities there was a desperate need to develop economic resource, as small industries in many regions, which provided to local economy as well as to the identity in the GDR, got lost with the collapse of socialist system. Centrally organized retail such as printing-, textile and auto industry in Thuringia had to close in the new competitive market economy. Instead, in the big hole of economy, the rich cultural assets caught the attention of the possibility to revitalize the region. Privatization and commercialization pulled the economic potentials of the cultural heritage. It brought economic benefits such as jobs, income, and infrastructure. This did not only contribute to the development of tourism but also upgraded local reputation by promoting its classic history, which brings nostalgic memories for Germany as one unified nation.

Talking about the past and personal experiences during the GDR is still an uneasy issue. In a relation to the system how the memory has been modified or merchandised is a challenging question for each of the community members. However, this discussion will bring benefits not only to Germany but also to many other places with fractured stories like Korea, Bosnia, Nicosia, etc. The heritage moves on and so does tourism development. Meanings have been changed and the spotlight has been turning around. Having a constant care and debating on cultural heritage is necessary because this is where the contemporary perspective is mirrored and also how today is going to be remembered in the coming decades.

\section{FOOTNOTES}

1 Please see Freyer Tourismus in den neuen Ländern 2000, pp. 218-219.

2 DZT: Deutsche Zentrale für Tourismus (in English GNTB: the German National Tourist Board). The Harz is the highest mountain range in Northern Germany across the three states of Lower Saxony, Saxony-Anhalt and Thuringia.

3 The Harz is the highest mountain range in Northern Germany across the three states of Lower Saxony, Saxony-Anhalt and Thuringia.

$4 \quad$ Please see "Tourism Concept 2011-2015 (Tourismus-konzeption 2011-2015)", Ministry of economic affairs, employment and technology of Thuringia), 2012.

5 Bezirk: in English region or district. It used to mean administrative division during the GDR period (1952-1990). The whole GDR was politically one state and 14 Bezirke and after the reunification, it has been returned to 5 states and Berlin, as it used to be in the earlier times.

6 Mrs. Gudrun Holzhäuser (64, pensioner), has worked over 40 years in Gotha and lives in Weimar.

7 Mrs. Heidi Böhme (78, pensioner), lives in Weimar.

\section{REFERENCES}

Allison, E. \& Peters, L. (2011). Historic preservation and the livable city. Hoboken, N.J.: Wiley; Chichester: John Wiley [distributor]

Ashworth, G. J. \& Graham, B. J. (2005). Senses of place. Senses of time. Aldershot, England, Burlington, VT: Ashgate (Heritage, culture, and identity).

Ashworth, G. J. \& Larkham, P. J. (1994). Building a new heritage. Tourism, culture, and identity in the new Europe / ed. by G.J. Ashworth and P.J. Larkham. London, New York: Routledge.

Deutscher Tourismusverband E. V. (2002). Neue Fachreihe Praxisleitfaden Wellness, Bonn

Freyer, W. (2000). Tourismus in den neuen Bundesländern. Eine Bestandsaufnahme 10 Jahre nach der deutschen Wiedervereinigung; Tagungsband zum 4. Dresdner TourismusSymposium. Dresden: FIT-Verl.

Freistaat Thüringen Ministerium für Wirtschaft, Arbeit und Technology (2012). Landestourismuskonzeption 2011-2015, Erfurt

Freistaat Thüringen Ministerium für Wirtschaft. Retreived from http:// www.wir-thueringen.de/tourismusbranche-thuringen-aufwachstumskurs on 14.03.2015

Gesetzblatt Teil I Nr. 26. Ausgabetag: (27. Juni 1975) 
Graham, B. J. \& Howard, P. (2008). The Ashgate research companion to heritage and identity. Aldershot: Ashgate (Ashgate research companion).

Harrison, R. (2013). Forgetting to remember, remembering to forget: late modern heritage practices, sustainability and the 'crisis' of accumulation of the past. International Journal of Heritage Studies 19(6), pp. 579-595. DOI: 10.1080/13527258.2012.678371.

Jensen, G. S. (2013). Strukturen und entwicklungstrends im deutschland tourismus. [S.I.]: Grin Verlag.

Kearns, G., \& Philo, C. (1993). Selling places. The city as cultural capital, past and present. 1st ed. Oxford [England], New York: Pergamon Press (Policy, planning, and critical theory).

Lowenthal, D. (1985). The past is a foreign country. Cambridge: Cambridge University Press.

Passi, I. B. S. (1999). Algebra. Some recent advances. Basel, Boston, Berlin: Birkhäuser (Trends in mathematics).

Schabe, P. (1992). Denkmalschutz in den neuen Ländern. Wer fördert was? 2. Aufl. Stand: Okt. 1991, Materialsammlung 1991. Bonn.

Schmidt, L. (2008). Architectural conservation: an introduction. Berlin: Westkreuz-Verl.

Thüringen Ministerium für Wirtschaft, Arbeit und Technologie: Landestourismuskonzeption 2011-2015, 2012 Accessed on $1 / 7 / 2015$.

Wolter, H. (2009). "Ich harre aus im Land und geh, ihm fremd". Die Geschichte des Tourismus in der DDR. Frankfurt am Main [u.a.] Campus-Verl (Beiträge zur historischen Verkehrsforschung, 10).

Wirtschaftsfaktor Tourismus in Thüringen Endbericht (2009). dwifConsulting $\mathrm{GmbH}$, München

Fig. 1. The state of Thuringia in Germany, Weltkarte.com Retreived from http://www.weltkarte.com/europa/deutschland/ bundeslaender.htm.

Fig. 2. Thuringia Geography, Thüringen Tourismus. Retreived from http://www.thueringen.info/tourismus.html.

Fig. 3. Ministry of economic affairs, employment and technology of Thuringia, Tourismuskonzeption 2011-2015, 2012, p. 38.

Datum prijave rada: 15.01.2015.

Datum prihvatanja rada: 24.04.2015

\section{Kontakt}

Younkyoung Sung, Bauhaus University Weimar,

Geschwister-Scholl-Straße 8, Weimar, Deutchland,

E-mail: younkyoung.sung@uni-weimar.de 